\title{
Numerical Simulation of Artificical Hip Joint Movement for Western and Japanese-Style Activities
}

\author{
Eko Saputra ${ }^{a^{*}}$, Iwan Budiwan Anwara, Rifky Ismailb, J. Jamarib, Emile van der Heide ${ }^{a}$ \\ a Laboratory for Surface Technology and Tribology, Faculty of Engineering Technology, Drienerlolaan 5, Postbus 217, 7500 AE Enschede, The \\ Netherlands \\ ${ }^{b}$ Laboratory for Engineering Design and Tribology, Department of Mechanical Engineering, University of Diponegoro, JI. Prof. Sudharto Kampus UNDIP \\ Tembalang, Semarang 50275, Indonesia \\ *Corresponding author: ekosaputro984@gmail.com
}

\section{Article history}

Received :17 December 2013

Received in revised form :

12 January 2014

Accepted :25 January 2014

\section{Graphical abstract}

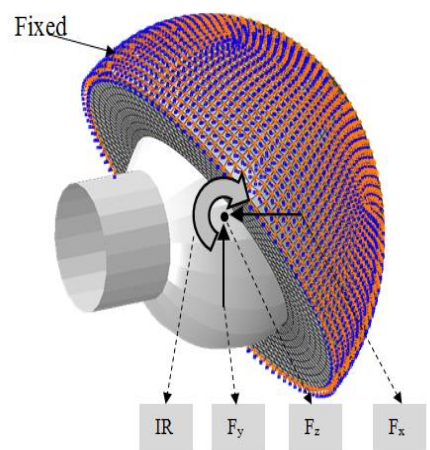

\section{Abstract}

A numerical simulation model for observing the artificial hip joint movement with respect to the range of motion during human activities is presented in this paper. There were two human activities discussed, i.e. Western-style and Japanese-style. Previous investigation has reported the range of motion on the artificial hip joint for Western-style and Japanese-style, measured from the postoperative total hip arthroplasty patients. The aim of this investigation is to observe the probability of prosthetic impingement and to calculate the von Mises stress during these activities using finite element analysis (FEA). The Westernstyle activities consist of picking up, getting up and sitting, while the Japanese-style activities consist of sitting on legs with fully flexed at the knee (seiza), squatting and sitting on legs with fully flexed at the knee (zarei). The FEA uses a three-dimensional nonlinear model and considers the variation of the acetabular liner cup positions. Result shows that a prosthetic impingement is found in the Western's picking up activity. This activity induces a prosthetic impingement in a certain the acetabular liner cup position. In the Japanese-style activities there is no prosthetic impingement observed. However, a critical value in the range of motion was observed for the Japanese's Zarei activity for certain the acetabular liner cup position. The acetabular liner cup positions influences the probability of prosthetic impingement.

Keywords: Finite element analysis; artificial hip joint; range of motion; human activities; impingement

\section{Abstrak}

Model simulasi berangka untuk memerhatikan gerakan sendi pinggul tiruan terhadap gerakan manusia ditunjukkan dalam kajian ini. Terdapat dua jenis gaya pergerakan manusia dibincangkan, iaitu gaya-Barat dan gaya-Jepun. Kajian sebelum ini telah melaporkan pelbagai gerakan pada sendi pinggul tiruan untuk gaya-Barat dan gaya-Jepun telah diukur daripada jumlah pesakit postoperatif arthroplasti pinggul. Tujuan penyelidikan ini adalah untuk melihat kebarangkalian pelampiasan tiruan dan mengira kadar tekanan von Mises dengan menggunakan analisis unsur terhingga (FEA). Pergerakan gaya-Barat melibatkan pergerakan mengambil, bangun dan duduk, manakala pergerakan gaya-Jepun dari duduk dengan dua kaki di bawah (seiza), membongkok dan duduk berlutut kehadapan (Zarei). FEA secara model linear tiga dimensi dan mengambil kira pelbagai posisi acetabular telah digunakan. Dapatan kajian menunjukkan bahawa pelampiasan tiruan berlaku bagi pergerakan gaya-Barat. Namun tiada pelampiasan dalam pergerakan gaya-Jepun. Walau bagaimanapun, nilai kritikal dalam pergerakan diperhatikan pada acetabular untuk pergerakan Zarei. Kedudukan acetabular dilihat mempengaruhi pelampisan pada sendi pinggul tiruan.

Kata kunci: Analisis unsur terhingga; sendi pinggul tiruan; pelbagai gerakan; aktiviti manusia; pelampiasan

(C) 2014 Penerbit UTM Press. All rights reserved.

\subsection{INTRODUCTION}

Dislocation is one of the main problems for total hip arthroplasty (THA) patient during their daily activities [1]. There are two types of dislocation: early dislocation and late dislocation [2]. The early dislocation occurs due to the impingement of the femoral neck from the acetabular liner cup lip and the late dislocation is mostly related to wear [2-3]. The impingement in early dislocation is induced by the limitation of the range of motion (RoM) of the artificial hip joint for the THA patient. This limitation of the RoM can be influenced by the femoral head diameter, femoral neck diameter and acetabular liner cup position. Human activities have 
different ranges of motion. The excessive or inordinate activities can induce a higher RoM and causes the impingement. THA patients will get typical procedures from their orthopedics specialist for doing activities in order to avoid the impingement.

Activities of the THA patients and its implication to RoM and impingement have been reported. Sugano et al. [4] presented the measurement of RoM for Western-style activities and Japanese-style activities. The measurement was conducted using the measurement results of 19 postoperative THA patients. It was reported that the RoM of the Western-style activities consist of picking up, getting up and sitting, while the RoM of the Japanesestyle activities consist of seiza, squatting and zarei. Kluess et al. [5] developed a three-dimensional model for artificial hip joint movement by finite element analysis. Several position of the acetabular liner cup during the movement was simulated in order to observe the occurrence of impingement. This paper presents a 3D movement simulation to study the RoM of the Western-style and Japanese-style activities. The impingement is then predicted by a finite element analysis. The relation of the resisting moment, the internal rotation and the von Mises stress are reported in this paper.

\subsection{EXPERIMENTAL}

\subsection{Material Model}

The finite element model of the contact system in the present study consists of femoral head, femoral neck and acetabular liner cup. The femoral head and the femoral neck component are assumed to be rigid. The acetabular liner cup component is modeled as an elastic-plastic material with isotropic hardening and assuming a visco-elastic-plastic material behavior of the ultrahigh-molecular-weight polyethylene (UHMWPE). The modulus of elasticity, the Poisson's ratio and the yield strength of the UHMWPE are set to $945 \mathrm{MPa}, 0.45$ and $23.56 \mathrm{MPa}$, respectively [6]. The plastic strain is calculated based on the work of Fregly et al. [7], see the graph in Figure 1:

$\varepsilon=\frac{1}{2} \varepsilon_{0} \frac{\sigma}{\sigma_{0}}+\frac{1}{2} \varepsilon_{0}\left(\frac{\sigma}{\sigma_{0}}\right)^{n}$

where the material parameter, $n$, is equal to 3 .

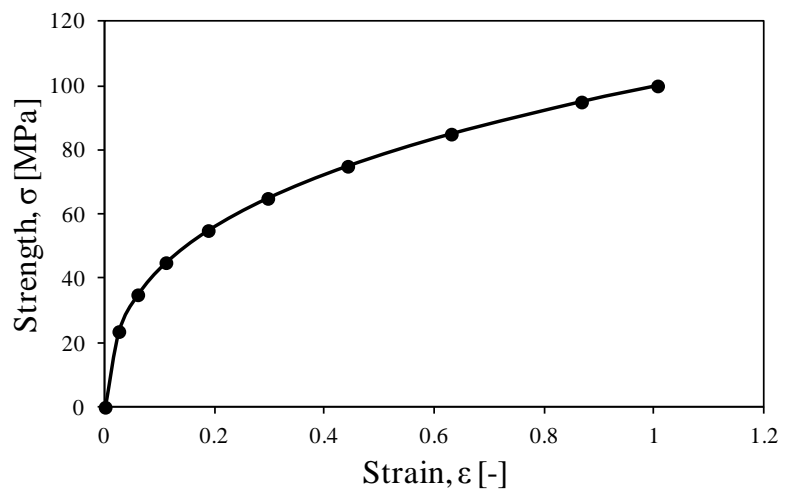

Figure 1 The plastic strain curve

\subsection{Finite Element Method}

\subsubsection{Geometry}

The geometrical modeling of the unipolar artificial hip joint follows the model of Kluess et al. [5], as is depicted in Figure 2(a). Diameter of the femoral head and the femoral neck are 28 $\mathrm{mm}$ and $14 \mathrm{~mm}$, respectively. The thickness of the acetabular liner cup is $7 \mathrm{~mm}$. A gap between the femoral head and the acetabular liner cup is $24 \mu \mathrm{m}$ and it is modeled as a lubrication space.

Figure 2(b) shows the finite element meshes for the acetabular liner cup. The commercial finite element software ABAQUS is employed. The element type of hexahedral 8 nodes linear brick (C3D8R) is employed, while the number of the element is approximately 9000.
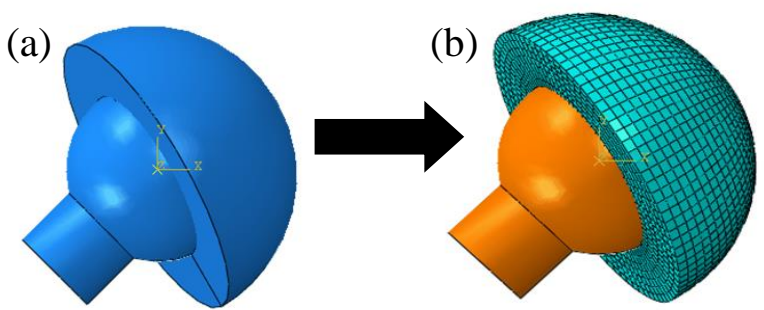

Figure 2 (a) Model of the femoral head and the acetabular liner cup and (b) the finite element meshes of the acetabular liner cup

\subsubsection{Boundary Conditions}

The value of the applied load of the present model is taken from the work of Kluess et al. [5], but the direction of the load follows the work of Bergmann et al. [8]. The loads in the $\mathrm{x}, \mathrm{y}$ and $\mathrm{z}$ directions are $F_{x}=15 \mathrm{~N}, F_{y}=270 \mathrm{~N}$ and $F_{z}=-427.5 \mathrm{~N}$, respectively, and are applied on a point at the center of the femoral head, see Figure 3. All the degree of freedom at the outer surface of the acetabular liner cup is constrained.

The simulation is conducted in two steps: firstly, the load is applied to the center of the femoral head with constraining the rotation of the femoral head is constrained and secondly, the load at the center of the femoral head is constrained with rotating the femoral head. The range of the internal rotation (IR) is according to the RoM of human activities.

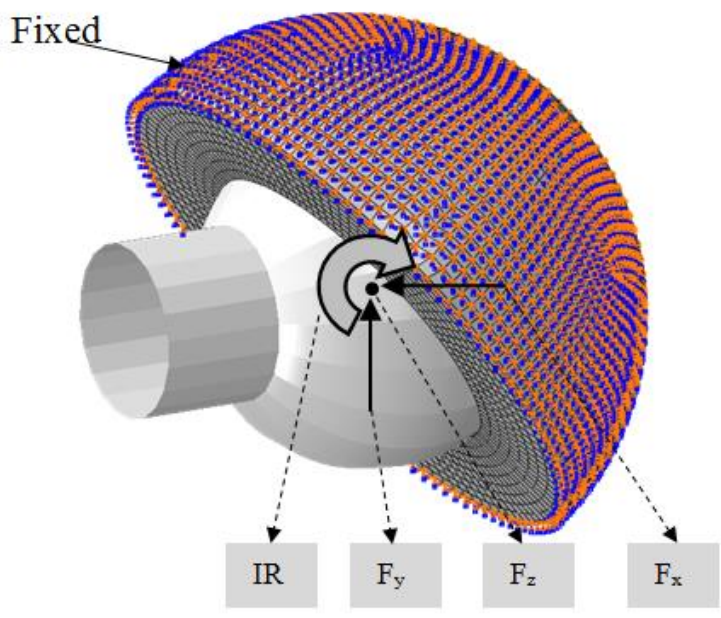

Figure 3 Boundary conditions on finite element model 


\subsubsection{Human Activities}

The simulations are performed for the Western-style and the Japanese-style activities. Here, the value of the RoM is taken based on the work of Sugano et al. [4]. The Western-style activities consist of picking up an object while sitting on the chair, getting up from the chair, and sitting down on the chair. The Japanese-style activities consist of bowing while sitting on legs with fully flexed at the knee (zarei), squatting, and sitting on legs with fully flexed at the knee (seiza).

Figures for expressing all these activities can be seen in Figure 4 [4]. Those activities give a certain value of the RoM in degree. Maximum flexion, adduction and internal rotation are the component items for the RoM value. Table 1 shows the value of RoM for the human general activities.

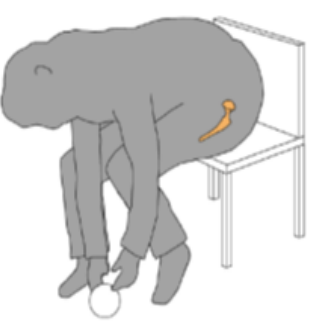

(a)

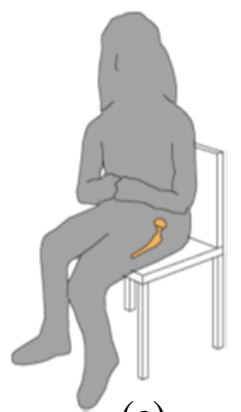

(c)

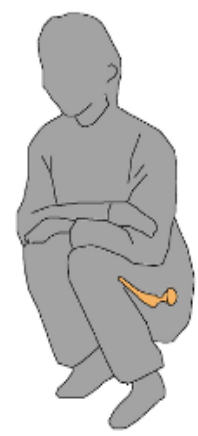

(e)

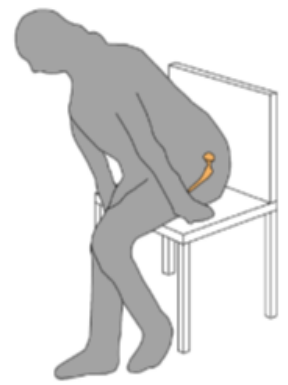

(b)

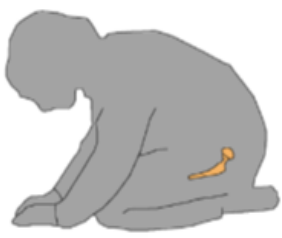

(d)

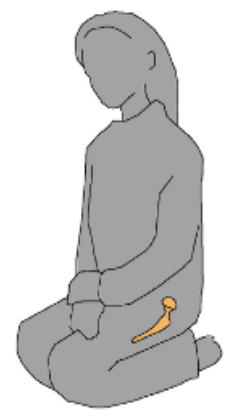

(f)
Figure 4 (a) Picking up an object while sitting on the chair, (b) Getting up from the chair, (c) sitting down on the chair, (d) Bowing while sitting on legs fully flexed at the knee (zarei), (e) squatting, and (f) sitting on legs fully flexed at the knee
Table 1 Hip joint angle $\left[{ }^{\circ}\right]$ during human activities [4]

\begin{tabular}{|c|c|c|c|}
\hline \multirow[b]{2}{*}{ Motion, Degree } & \multicolumn{3}{|c|}{ Average \pm Standard deviation } \\
\hline & $\begin{array}{l}\text { Max } \\
\text { Flexion }\end{array}$ & Adduction & $\begin{array}{l}\text { Internal } \\
\text { Rotation }\end{array}$ \\
\hline \multicolumn{4}{|l|}{$\begin{array}{l}\text { Western-style activities on } \\
\text { the chair }\end{array}$} \\
\hline $\begin{array}{l}\text { Picking up an object while } \\
\text { sitting on the chair }\end{array}$ & $86 \pm 13$ & $-6.1 \pm 7.3$ & $-12 \pm 11$ \\
\hline Getting up from the chair & $76 \pm 12$ & $-2.5 \pm 5.2$ & $-11 \pm 10$ \\
\hline Sitting down on the chair & $62 \pm 10$ & $-0.92 \pm 5.5$ & $-7.0 \pm 11$ \\
\hline \multicolumn{4}{|l|}{$\begin{array}{l}\text { Japanese-style activities on } \\
\text { the floor }\end{array}$} \\
\hline $\begin{array}{l}\text { Bowing while sitting on legs } \\
\text { fully flexed at the knee } \\
\text { (zarei) }\end{array}$ & $84 \pm 13$ & $-2.1 \pm 4.9$ & $-12 \pm 11$ \\
\hline Squatting & $80 \pm 16$ & $-8.6 \pm 9.5$ & $-9.2 \pm 11$ \\
\hline $\begin{array}{l}\text { Sitting on legs fully flexed at } \\
\text { the knee (seiza) }\end{array}$ & $61 \pm 12$ & $-1.2 \pm 4.4$ & $-15 \pm 11$ \\
\hline
\end{tabular}

\subsubsection{Variation}

The variation of the angle between inclination and anteversion of the acetabular liner cup is simulated in order to study the possibility of the impingement to occur between the femoral neck and the acetabular liner cup lip. The variations of inclination of the acetabular liner cup are $45^{\circ}$ and $60^{\circ}$ and the variation of anteversion of the acetabular liner cup are $15^{\circ}$ and $30^{\circ}$. The angle of the femoral neck axis line and the femoral stem axis line is $135^{\circ}$. The simulation uses a femoral head diameter of $28 \mathrm{~mm}$. The variations in the present study follow the work of Kluess et al. [5].

\subsection{RESULTS AND DISCUSSION}

\subsection{Validation}

In order to check the developed model simulation, a validation was conducted by comparing the results to the work of Kluess et al. [5]. The inclination and anteversion of the acetabular liner cup were fixed for $60^{\circ}$ and $30^{\circ}$, respectively. Result of the validation is shown in Figure 5. The average deviation between the present model and the Kluess et al. model is about $1.32 \%$. The developed model is in good agreement with literature with respect to the predicted resisting moment.

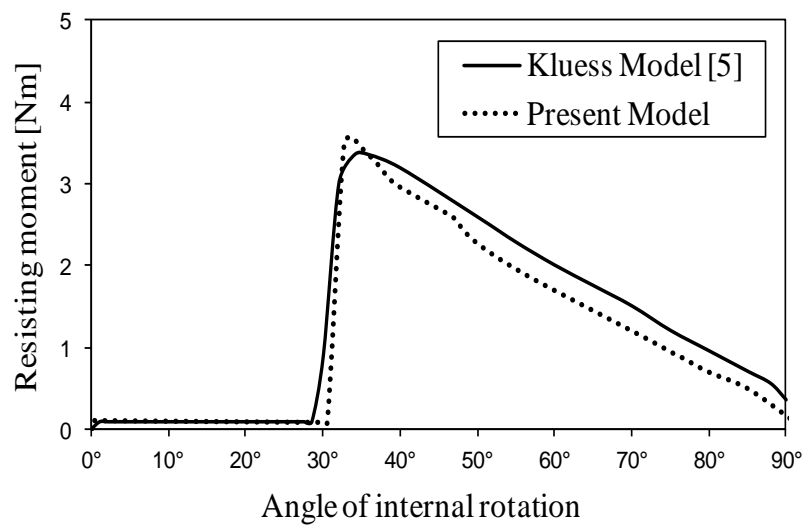

Figure 5 Comparison between the present model and the Kluess model [5] in predicting the resisting moment as a function of the angle of internal rotation 


\subsection{Western-style Activities}

Figure 6(a) and 6(b) show the degree of impingement for the Western-style activities. In Figure 6(a) the internal rotation for the picking-up, getting-up and sitting down activities is reported with considering four different position of the acetabular liner cup. The minimum requirements of the internal rotation for picking-up, getting-up and sitting down activities are $12^{\circ}, 11^{\circ}$ and $7^{\circ}$, respectively. The highest resisting moments for picking-up, getting-up and sitting down activities are $4.41 \mathrm{Nm}, 3.88 \mathrm{Nm}$ and $3.21 \mathrm{Nm}$ as is depicted in Figure 6(b).

The unipolar artificial hip joint does not induce an impingement for most of the Western-style activities. Yet, the picking up activity, for the acetabular liner cup inclination of $45^{\circ}$ and anteversion of $15^{\circ}$, could be critical as the impingement is predicted to occur at $8^{\circ}$ of the internal rotation. Therefore, the THA patients are suspected not to be able to finish the picking up activity due to the fact that it needs at least $12^{\circ}$ of internal rotation.

(a)
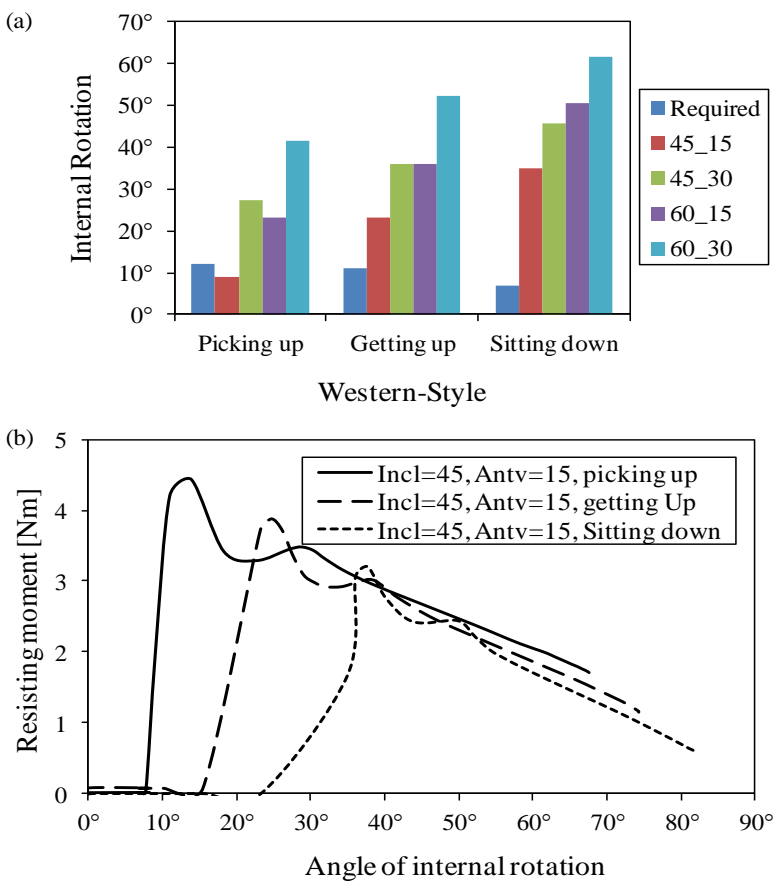

Figure 6 (a) Comparison of the calculated value of internal rotation obtained from variations of the acetabular liner cup position in the Western-style activities and (b) plot of its resisting moment as a function of its internal rotation angle

Figure 7 shows the von Mises stress analysis. Figure $7(\mathrm{a}, \mathrm{c})$ shows the stress analysis for getting up activity, Figure $7(\mathrm{~b}, \mathrm{~d})$ shows the picking up activity, and Figure 7(e) shows the sitting down activity, where the combination degree of the acetabular liner cup inclination and the anteversion is $45^{\circ}-15^{\circ}$. Two impingement positions can be found from the analysis based on this figure, namely impingement site and egress site.

Dislocation is predicted to occur for the patients who are trying to perform the picking up activity. The other combination positions of the acetabular liner cup for inclination and anteversion are also reported in a safe position, $45^{\circ}-30^{\circ}, 60^{\circ}-15^{\circ}$ and $60^{\circ}-30^{\circ}$. (a)
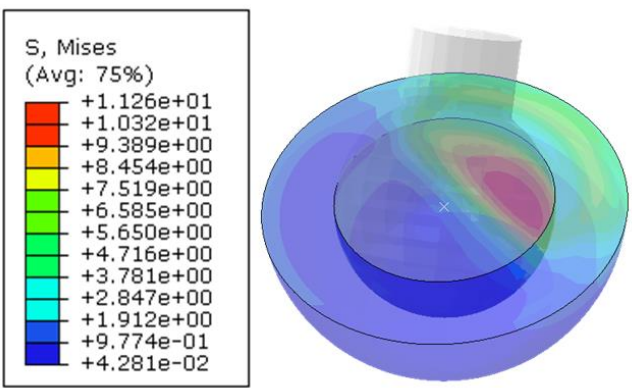

(b)
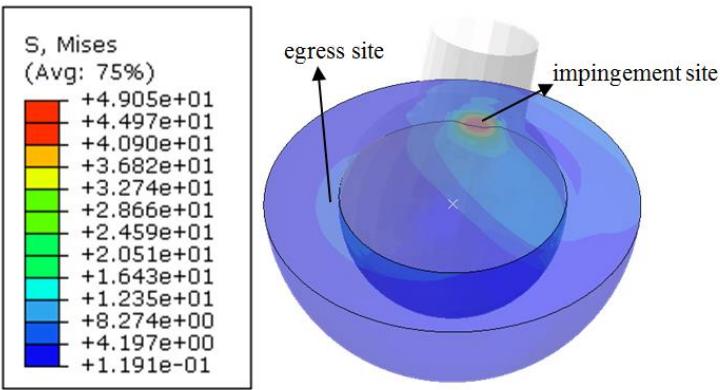

(c)
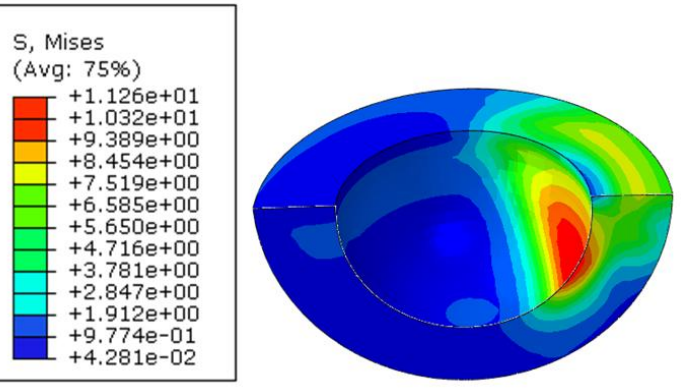

(d)
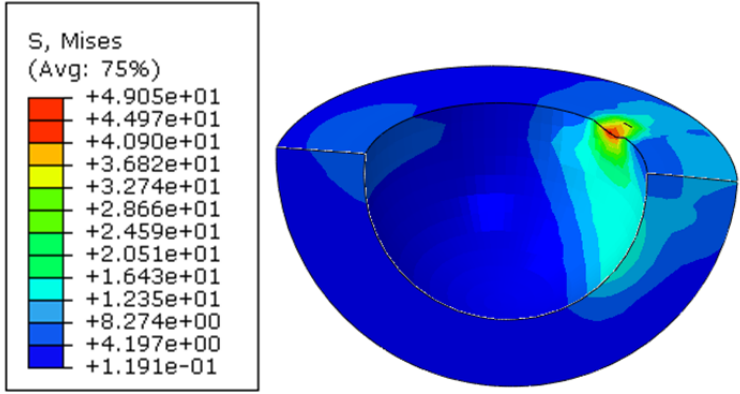

(e)
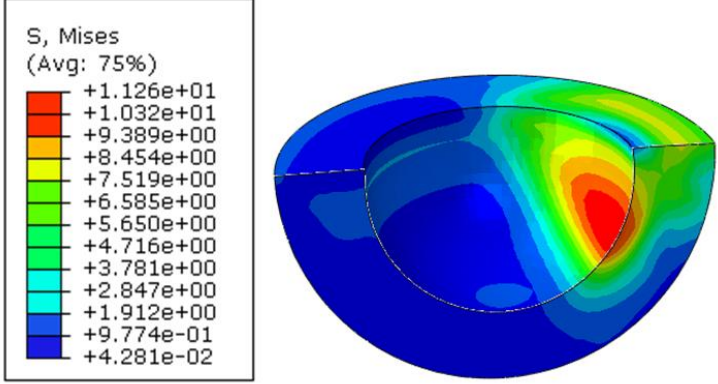

Figure 7 The von Mises stress for: a,c) the full and half of acetabular liner in getting up activity, b,d) full and half of acetabular liner in picking up activity, and e) half of acetabular liner in sitting down activity, where the acetabular liner cup position is $45^{\circ}$ inclination and $15^{\circ}$ anteversion of the Western activity 
However, based on several testimonies of the orthopedic specialist, it is stated that the inclination and the anteversion of the acetabular liner cup combinations of $45^{\circ}-15^{\circ}$ are mostly used. It is suggested that the unipolar artificial hip joint, proposed by Kluess et al. [5], need to be redesigned to accommodate the picking up activity with respect to the inclination and the anteversion of the acetabular liner cup combination of $45^{\circ}-15^{\circ}$.

\subsection{Japanese-style Activities}

The degree of impingement for the Japanese-style activities is shown in Figure 8. In Figure 8(a) the internal rotation for the three activities is reported with considering four positions of the acetabular liner cup. The minimum requirements of the internal rotation for zarei, squatting and seiza activities are $12^{\circ}, 9.2^{\circ}$ and $15^{\circ}$, respectively. Figure $8(\mathrm{~b})$ shows that the highest resisting moment for zarei, squatting and seiza activities are $4.33 \mathrm{Nm}, 4.10$ $\mathrm{Nm}$ and $3.15 \mathrm{Nm}$, respectively.

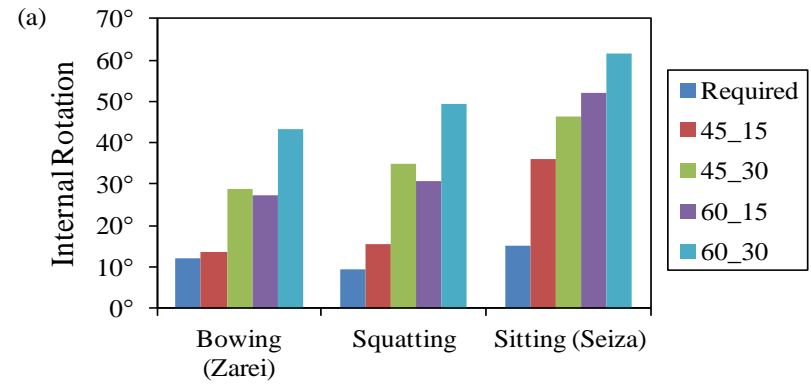

Japanese-Style

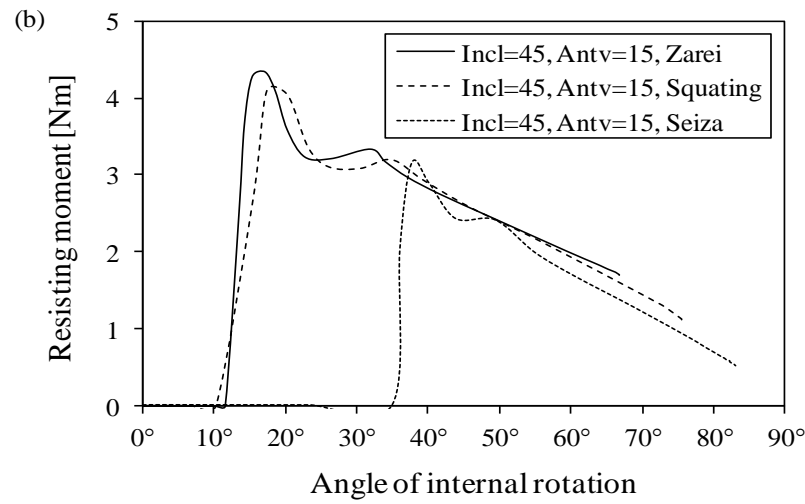

Figure 8 (a) Comparison of the calculated value of internal rotation obtained from variation of the acetabular liner cup position in the Japanese-style activities and (b) plot of its resisting moment as a function of its internal rotation angle

In general, the unipolar artificial hip joint models for the Japanese-style activities are predicted safe in term of the impingement. However, the zarei activity, for inclination of $45^{\circ}$ dan anteversion of $15^{\circ}$ of the acetabular liner cup, is still not suggested. This is because the impingement of the zarei activity is predicted to occur at $13.53^{\circ}$ of internal rotation whiles the result shows that the required degree of the zarei activity is $12^{\circ}$. Moreover, the safe margin of the internal rotation is about $10^{\circ}$ as was suggested by Sugano et al. [4]. Therefore, an evaluation is still needed for the unipolar artificial hip joint model proposed by Kluess et al. [5]. The model needs to be redesigned for accommodating the zarei activity in a more safe condition. The von Mises stress contours for the Japanese-style activities are shown in Figure 9(a,c), 9(b,d) and 9(e) for squatting, zarei and seiza activities, respectively, with the combination of inclination and anteversion of the acetabular liner cup of $45^{\circ}-15^{\circ}$.

(a)
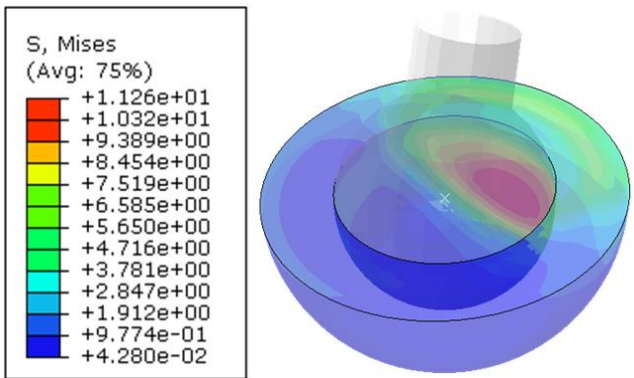

(b)
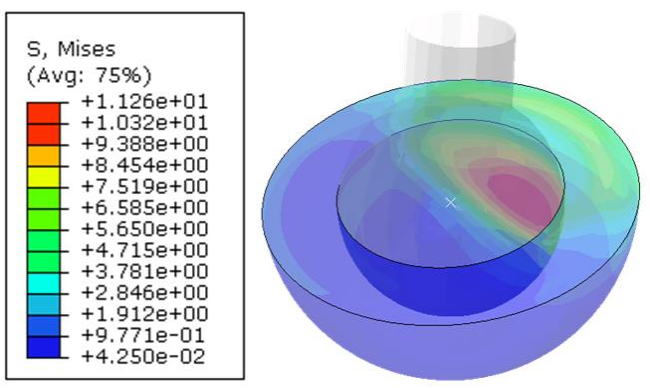

(c)
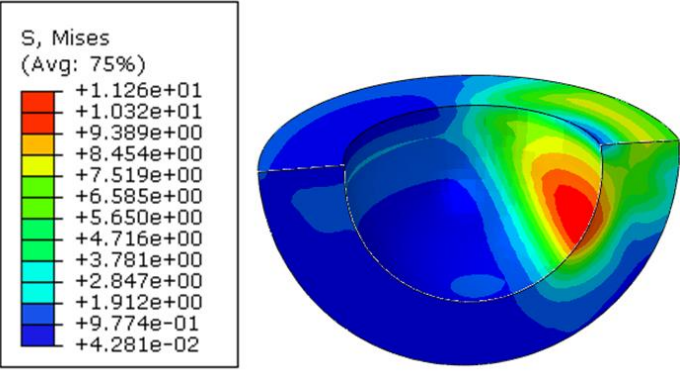

(d)
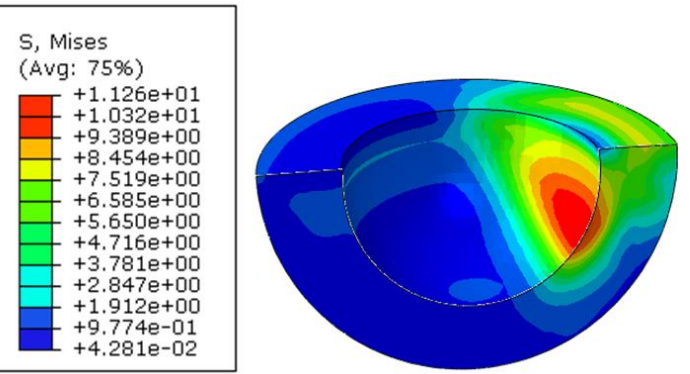

(e)
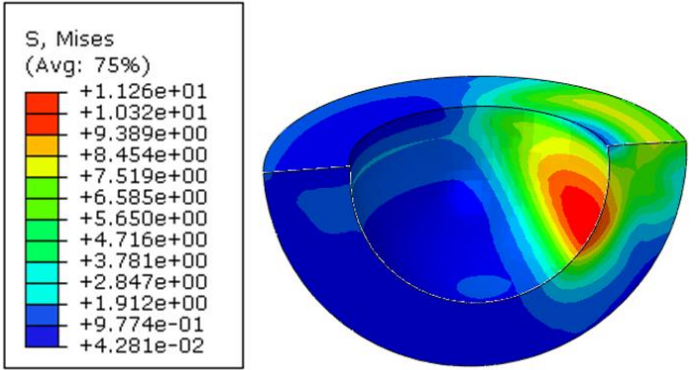

Figure 9 The von Mises stress for: $(\mathrm{a}, \mathrm{c})$ the full and half of acetabular liner in squatting activity, (b,d) the full and half of acetabular liner in zarei activity, and (e) half of acetabular liner in seiza activity, where the acetabular liner cup position is $45^{\circ}$ inclination and $15^{\circ}$ anteversion of the Japanese activity 


\subsection{CONCLUSION}

This paper investigated the range of motion of the human activities of the Western-style and the Japanese-style using finite element analysis for THA patient. The unipolar artificial hip joint model was used in the simulation. Based on the results it can be stated that for the THA patients the Western-style and Japanesestyle most activities can be performed safely. The impingement and dislocation are predicted to be occur at picking up activity in the Western-style activity for the inclination and anteversion combination of the acetabular liner cup of $45^{\circ}-15^{\circ}$. The seiza activity in the Japanese-style activitiy is not recommended to be performed for the THA patients because of the safety margin of the internal rotation is less than $10^{\circ}$. The impingement between the femoral neck and the acetabular liner cup lip during a contact situation can be predicted by the finite element simulation. It is demonstrated that the von Mises stress at the impingement position is higher than the yield strength of the material.

\section{References}

[1] Sikes, C. V., Lai, L. P., Schreiber, M., Mont, M. A., Jinnah, R. H., Seyler, T. M. 2008. Instability After Total Hip Arthroplasty Treatment with Large Femoral Heads vs Constrained Liners. The Journal of Arthroplasty. 23(7): 59-63.

[2] Cuckler, J. M. 2011. The Dislocated Total Hip: The Dreaded 3 AM Phone Call, Seminars in Arthroplasty. 22: 98-99.

[3] Hummel, M. T., Malkani, A. L., Yakkanti, M. R., Baker, D. L. 2009. Decreased Dislocation After Revision Total Hip Arthroplasty Using Larger Femoral Head Size and Posterior Capsular Repair. The Journal of Arthroplasty. 24(6): 73-76.

[4] Sugano, N., Tsuda, K., Miki, H., Takao, M., Suzuki, N., Nakamuro, N. 2012. Dynamic Measurements of Hip Movement in Deep Bending Activities After Total Hip Arthroplasty Using a 4-Dimensional Motion Analysis System. The Journal of Arthroplasty. 27(8): 1562-1568.

[5] Kluess, D., Martin, H., Mittelmeier, W., Schmitz, K. P., Bader, R. 2007. Influence of Femoral Head Size on Impingement, Dislocation and Stress Distribution in Total Hip Replacement. Medical Engineering \& Physics. 29: 465-471.

[6] Eichmiller, F. C., Tesk, J. A., Croarkin, C. M. 2001, Mechanical Properties of Ultra High Molecular Weight Polyethylene NIST Reference Material RM 8456, In: 'Transactions of the Society for Biomaterials, 27th Annual Meeting. 472.

[7] Fregly, B. J., Bei, Y., Sylvester, M. E. 2003. Experimental Evaluation of An Elastic Foundation Model to Predict Contact Pressures in Knee Replacements. Journal of Biomechanics. 36: 1659-1668.

[8] Bergmann, G., Graichen, F., Rohlmann, A. 1993. Hip Joint Loading During Walking and Running, Measured in Two Patients. Journal of Biomechanics. 26: 969-990. 